\title{
JOINT DEVELOPMENT OF NOVEL BUSINESS MODELS
}

\author{
Jukka Heikkilä $^{1}$, Marikka Heikkilä ${ }^{2}$ and Jari Lehmonen ${ }^{2}$ \\ ${ }^{I}$ Department of Computer Science and Information Systems, University of Jyväskylä, P.O. Box \\ 35 (Agora), FI-40014 FINLAND; ${ }^{2}$ Information Technology Research Institute, University of \\ Jyväskylä, P.O. Box 35 (Agora). FI-40014 FINLAND
}

\begin{abstract}
Changing competitive environment forces companies to innovate and renew their business models towards a more value-adding and customer-centric direction. Often, a prerequisite for this is that the companies are willing to combine their capabilities by co-operating and creating long-term strategic networks with each other. The formation of networks is a cyclical learning process, along which the infrastructure and strategies emerge incrementally through mutual adjustment.

We analyze such network formation process among three companies that are operating in separate but complementary industries. They are seeking to expand their service offering through the use of ICT. We reflect upon this development with the state-of-the-art research on the networked organizations and business models. It seems that business models are necessary and useful in depicting the areas of adjustments within and between the organizations in the networked setting.
\end{abstract}

Key words: e-business; business model; ICT; networked organization; knowledge creation; knowledge Sharing.

\section{INTRODUCTION}

The transformation to digital economy is a search for innovative interlinked, strategic business networks, e-powered commerce and interorganizational systems. The companies are forming firmer relationship with 
strategic partners, more often with a few chosen contractors which are given the responsibility for larger entities than before (as predicted by Clemons et al, 1993). The coordination of transactions is achieved through - instead of hierarchy or markets - the interaction and mutual obligation of the firms in the network (Powell, 1990).

For decades, the new ideas for technology enabled businesses were created by one party, which then appropriated the business benefits by obtaining required additional resources and capabilities to implement and learn innovations' potential (e.g. Cohen \& Levinthal, 1990). Nowadays, the tendency of firms to focus on their core competencies and with increasing degree of outsourcing, have made the companies more dependent on each other's knowledge and capabilities (Soekijad \& Andriessen, 2003; Powell, 2000; Dyer \& Singh, 1998). As a result, also new business ideas seldom are feasible for a single company only, but require co-operation between multiple firms. This tendency is further leveraged due to technological complexity of new innovations (Hagedoorn and Duysters, 2002). As Powell, 2000 states it:

"The boundaries of many firms have become so porous that to focus on boundaries means only to see trees in a forest of interorganizational relations. The core competence of a firm, to use the new argot, is based on knowledge production and building a sustainable advantage that can be leveraged across products and services, thus enmeshing firms in all manner of different relationships and markets that were traditionally called industries. Power, to be sure, remains crucial, but it is employed to enhance reach and access and to compete in high-speed learning races. These new innovations are inherently fragile because they are premised on obtaining deeper engagement and participation from "core" employees and more collaboration and mutual involvement among ostensible competitors. But employees toil in a context of greater labor market volatility and inter-firm cooperation coexists with rivalry among competing networks." (Powell, 2000, p. 5)

Hence, also the know-how required for the creation of new innovative business ideas is dispersed into multiple organizations. To large extent, innovation derives from knowledge exchange and learning between firms (Nooteboom, 2000), which is also reflected in their strategic intentions towards simultaneous competition and co-operation (Nalebuff \& Brandenburger, 1996). All this - i.e., need for shared resources, and shared knowledge creation between partners, competitors and/or customers combined with favorable strategic intent and technical means - makes co-operation networks between firms in creation and realization of new business ideas a tempting option. The phenomenon is getting ever more topical with the ad- 
vent of ICT-facilitated business models, as they are growingly based on the idea of fluent co-operation and information exchange between the parties (see e.g., Ciborra \& Hanseth, 1998; Ciborra \& Andreu, 2001).

Our discussion is related to the literature on business models (e.g. Osterwalder \& Pigneur, 2002; Osterwalder, 2004; Faber et al, 2003; Bouwman, 2003; e-Factors, 2002), organizational learning (e.g. Cohen \& Levinthal, 1990; Ciborra \& Hanseth, 1998; Ciborra \& Andreu, 2001; Andersen \& Christensen, 2000) and strategic alliances (e.g. van de Ven, 1976; Powell, 1990; 2000; Kumar \& van Dissel, 1996; Nalebuff \& Brandenburger, 1996). Our viewpoint is closer to the infrastructural aspects of co-operation. This means that we look into the creation process of business model in a business network context, rather than on restructuring processes within an organization or within a supplier chain (e.g. Hammer, 1990), or on the strategy formulation process, or contractual issues. Unfortunately, previous literature has mainly focused on networks as given contexts for the organizations within them (Beugelsdijk et al., 2003). There are few studies on the initial formation of the network or creation of the joint business. Hence, the question arises how the companies come up with a business model that is feasible for each individual, independent company. In this article we focus on the necessary requirements for the joint business model. We claim that in order it to be acceptable to all parties, it should be in line with each of the participants business strategies and processes. This calls for a joint learning process at the network level, and parallel adjustments processes within each company.

In this paper we focus on creation of network business model by three independent business partners. We have a privilege to take actively part as researchers, probably also as conciliators and facilitators, in an establishment of this co-operation network. Despite the limited generalizability of our research, it offers a view on the outset of the cyclical evolution process of business network creation.

The article is organized as follows: In chapter 2 we will summarize the networked organizations concerns in global, ICT-enabled business. We illustrate the important aspects and emergent properties that have been found to affect formation of the business networks and organizational learning. This is to set the arena for discussion on business models, i.e., the creation of a joint business concept. Finally, we reflect upon the knowledge creation and sharing within the network, to sum up some of the findings for future research agenda. 


\section{WHY NETWORKED ORGANIZATIONS?}

\subsection{Networked organization forms}

The institutional economics (Coase, 1937; Williamson, 1985; Alchian and Demsetz, 1972; Jensen and Mecklin, 1973; Picot et al, 1997) concerned with the boundaries of the firm, contracts between co-operating parties, and 'make or buy "-decisions, generally positions networks as an intermediate governance form between markets and hierarchies. Williamson (1985) claims that, in the case of high uncertainty and asset specificity, parties have an incentive to protect their investments by realignment of incentives, creation of a specialized governance structure, or introduction of trading regularities that signal continuity of intentions of the parties. Specifically, assetspecific products often involve a long process of development and adjustments for the supplier to meet the needs of the client. This calls for continuity that can be ascertained within hierarchy or in close co-operation (Malone et al, 1987; Kumar and VanDissel, 1996; Gulati and Singh, 1998). It seems that when technological complexity of the product or service is high the companies more often prefer co-operation instead of mergers and acquisitions. For instance Hagedoorn and Duysters (2002) suggest that these kinds of flexible forms of organizations are appropriate because new knowledge expires quickly and requires timely learning. They can also be more easility adapted to changes under uncertainty. Instead of prices or authority/routines co-operation netwoks rely more on relational communication, free will and trust, and aims at benefiting all its partners (Powell, 1990; Tsupari et al., 2001; Beugelsdijk, 2003). The form of co-operative relationship may vary from single business transactions to annual contracts or projects to strategic partnership.

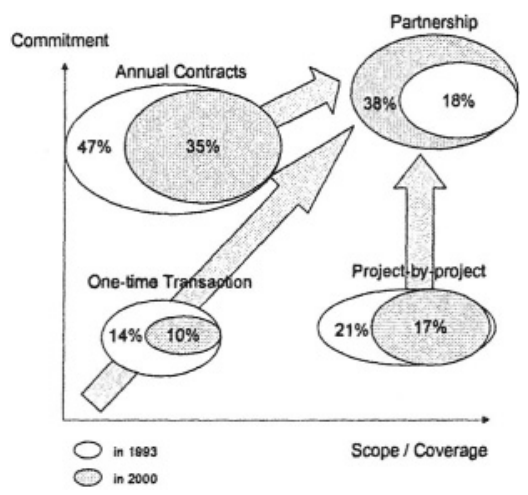

Figure 1. The evolution of manufacturing networks in Finland. (Tsupari et al., 2001) 
It seems that various kinds of networks in business have become common also in reality, for example a study by Tsupari et al. (2001) shows that over two thirds of companies in manufacturing industry in Finland ${ }^{30}$ are involved in networks to some extent. The tendency seems to be a move towards partnerships requiring higher levels of commitment and higher coverage of firms' operations (see figure 1. on the empirical results of the evolution of manufacturing networks in Finland).

Ultimately, the motivation for organizations to join a network is the attainment of goals that are unachievable by the organizations independently (as postulated by van de Ven, 1976). The firms may enter alliances in order to gain fast access to new technologies or new markets, or they may try to shape competition, or gain legitimacy (Powell, 1990; Nielsen, 2002). They may also share the costs of large investments, pool and spread risk, reduce the uncertainty, attain economies of scale or scope, etc. (Kumar and van Dissel, 1996). Traditionally the firms approach collaboration from a complementary or exploitation view; they seek for additional knowledge from other companies operating in similar or same domain. The aim is to find matching knowledge related capabilities that can be transferred, incorporated and appropriated in the assimilating firm (Nielsen, 2002; March, 1991). In this view, it is crucial that there is some similarity between the co-operating firms, for instance sameness of goals, services, staff skills, and clients (van de Ven, 1976), so that they can absorb the innovation within reasonable timeframe (Cohen \& Levinthal, 1990). This timeframe can be further shortened by improving the absorptive capacity within a firm by accumulating the capacity in particular areas (ibid., p. 136). But this approach is vulnerable in fast changing, uncertain situations.

An alternative motivation to form a business network may be to explore on external problem, or opportunity in the overlapping domains of organizations (van de Ven, 1976). In such cases the need emerges out of an awareness, for example of changing need priorities, resource distribution channels, or power relationships in the environment (van de Ven, 1976). This explorative and synergistic view challenges the traditional complementary view especially in knowledge intensive environments (Nielsen, 2002; March, 1991). Whereas the traditional complementary view is concerned with increasing productivity through standardization, systematic costs reduction, and incremental improvement of existing technologies, skills and capabili-

\footnotetext{
${ }^{30}$ Tsupari et al. (2001) reports findings of a mail survey carried out 2001. The questionnaires were posted to 700 manufacturing firms in Finland. The response rate was around $52 \%$ (363), accounting for $40 \%$ of the total personnel and $60 \%$ of the total net sales in the manufacturing industry. It is worth noting that around $60 \%$. of the products of manufacturing of metals and electronics is exported in 2002 (National Board of Customs, 2004).
} 
ties, exploration, in turn, is about finding new opportunities for wealth creation through building new capabilities and innovation. Nielsen (2002) pictures synergistic knowledge networks as networks where new knowledge can be created among the participants as a synergy (and not simply the sum). For example experimental activities such as prototyping, experimenting and conceptual testing can be used to ensure rapid gain of knowledge. We would expect these networks to be more of static type: they aim at achieving longterm goals, for example, by forming longer-lasting relationships (Hoogeweegen et al, 1999). However, as these explorative networks are concerned with new, innovative matters, they are facing more uncertainty in their tasks and outcomes. In line with real-life observations of business process reengineering projects, also many explorative networks may fail in achieving their objectives and break up after only a short trial period (see e.g. Sivadas \& Dwyer, 2000).

To summarize, business networks are considered especially useful for the exchange of qualities or commodities whose value is difficult to evaluate, like know-how, technological capability, a particular method or style of production, or a spirit of innovation or experiments (Powell, 1990). This implies that knowledge related capabilities are of central concern in the formation of networks. Therefore, we will next discuss the knowledge related issues of business networks.

\subsection{Business Networks as Arenas for Learning}

The original rationale in developing business networks was to enhance company specific assets and seek complementary resources and capabilities from partnering firms. Because of the path dependent nature of the absorption process, van de Ven (1976) and Kumar \& van Dissel (1996) pointed out that evolution of business network is an emergent and cyclical process over time. It simply takes time to build trust and learn to work together and adjust operation within the network: "The emergence and functioning of an IR (inter-organizational relationship), therefore, is a cyclical process of: need for resources - issue commitments - inter-agency communications to spread awareness and consensus - resource transactions - and structural adaptation and pattern maintenance over time" (van de Ven, 1976, p. 33).

This is well in line with the idea of absorptive capacity, too. Ability to recognize the value of new information and assimilate it is a function of level of prior knowledge. Prior knowledge enhances learning because events are recorded to memory by establishing linkages with pre-existing concepts. Absorptive capacity is, hence, history and path dependent (Cohen \& Levinthal, 1990), which means that it will be built incrementally on the existing knowledge, and most likely nowadays on ICT-infrastructure. Some amount 
of redundancy or knowledge spillovers may be desirable to create crossfunction absorptive capacity, which again makes organizations more capable of proacting (Cohen \& Levinthal, 1990). Basically, the longer the capacity has evolved the higher it grows, and the more proactive the organization can become. Some recent studies suggest that the relationship may be more contingent on the knowledge and infrastructure interplay than suggested above. For example, Ciborra \& Hanseth (1998) argue on the basis of longitudinal case studies that sometimes decentralized processes may speed up the adoption of new practices.

In addition to absorptive capacity Andersen and Christensen (2000) point out the importance of communicative capacity within the network. Their case study shows how poorly managed communication between firms may easily destroy long-standing and cumulative efforts of trust-building. Specifically diversity in culture, organization culture and strategy between the parties increases misunderstandings and difficulties to communicate (Andersen and Christensen, 2000). Communication capabilities can be, at least to some extent, be improved by establishing common experience and joint practices or developing a new jointly spoken language that facilitates cooperation (Ciborra \& Andreu, 2001). Also, an independent intermediary or conciliator/moderator (for example university) may help in the dialogue between the parties for example by providing unbiased background information, and translating the message of one party so that it is understandable to the other companies that have different domain and 'language'.

However, as Ciborra \& Andreu (2001) highlights a firm that is entering an alliance with another firm having its own knowledge management system and practices, may find its own internal knowledge management arrangements and resources "too rigid, 'closed' and incompatible". Thus, in addition to absorptive and communicative capabilities we need also development of synergistic knowledge networks and explorative knowledge creation (Nielsen 2002). Seeking business network as arenas for learning and linking capabilities into strategic intention we refer to the cyclic process described by Ciborra \& Andreu (2001). In their learning ladder model for a single firm they picture learning with three loops. The lowest loop is about routinization of the knowledge. A second loop is about transformation of 'abstracts' and 'constructs' capabilities from existing work practices. These capabilities are more abstract than work practices, they are 'skills without a place'. The third strategic loop, in turn, is concerned about selection of core capabilities from the capabilities in the context of competitive environment and business mission of the firm. Ciborra and Andreu (2001) carry on by proposing that there is another source of competitive advantage stemming from the establishment of interfirm linkages, recombination of separate learning ladders, which in themselves can become a distinct source of relational quasi-rents. "Valuable 
know-how can be attained by mixing and transferring capabilities, by placing resources and routines in new contexts or by letting existing practices be molded by different capabilities in order to form new routines". Governance of this phenomenon is vital in securing compatibility, transferability and value generation.

\section{BUSINESS MODELS - ARCHITECTURAL DE- SCRIPTIONS BETWEEN STRATEGY AND PROCESSES}

\subsection{Business models}

Business models have recently been a topical issue especially in the field of electronic commerce. Since the end of 90's (Osterwalder, 2004) there has been a vivid research stream proposing differing definitions, lists of components, taxonomies, change methodologies and evaluation models for business models (e.g Timmers, 1998; Amit \& Zott, 2001; e-Factors, 2002; Osterwalder \& Pigneur, 2002; Faber et al, 2003; Bouwman, 2003; Osterwalder, 2004). In essence, the topics discussed in the business model literature are not new: the components of business models have been recognized - at least to some extent - in business strategies and business planning for decades. But, the need for explicit analysis and description of the business model has become more evitable as the introduction of information and communication technology has enabled completely new ways of making business.

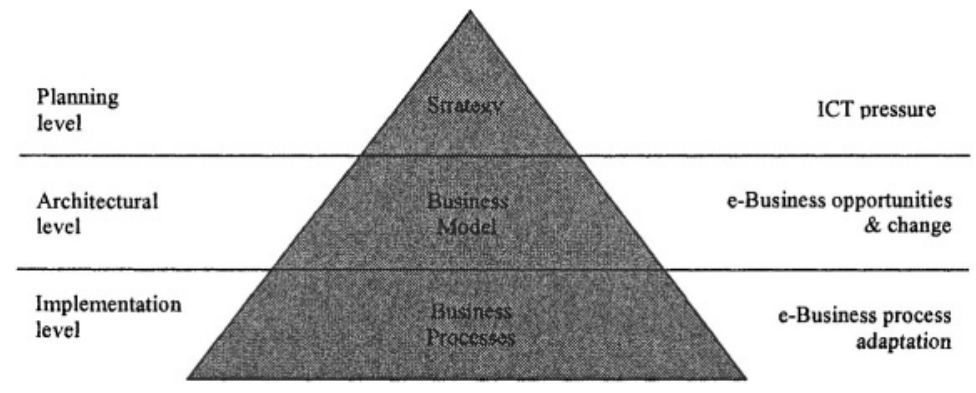

Figure 2. Business Logic Triangle (Osterwalder \& Pigneur, 2002) 
The general targets for the business actions are set in organizations strategy (see Figure 2). Business model mediates this organization strategy at an architectural level. It depicts how the business works, the general logic that creates the business value in relation with the organizations architecture/infrastructure. Thereby the business model, as a representation of the corporate strategy, is the starting point for planning operative business processes (e-Factors, 2002). Business model tells how the strategy is implemented by describing e.g. product offering, IT-infrastructure, financials customers and supplier relationships. Thus "the business model depicts the content, structure, and governance of transactions designed so as to create value through the exploitation of business opportunities" (Amit \& Zott, 2001).

Osterwalder and Pigneur point out that in its essence, a business model consists of four interrelated components (see Figure 3.): Product innovation component defines what business the company is in, and the product innovation and the value proposition offered on the market; Customer relationship aspects consider who are the target customers, how the service is delivered to them and how to build the relationship; Infrastructure management component is about how to perform efficiently infrastructure and logistics issues, and Financials component includes the revenue and costs model (Osterwalder \& Pigneur, 2002).

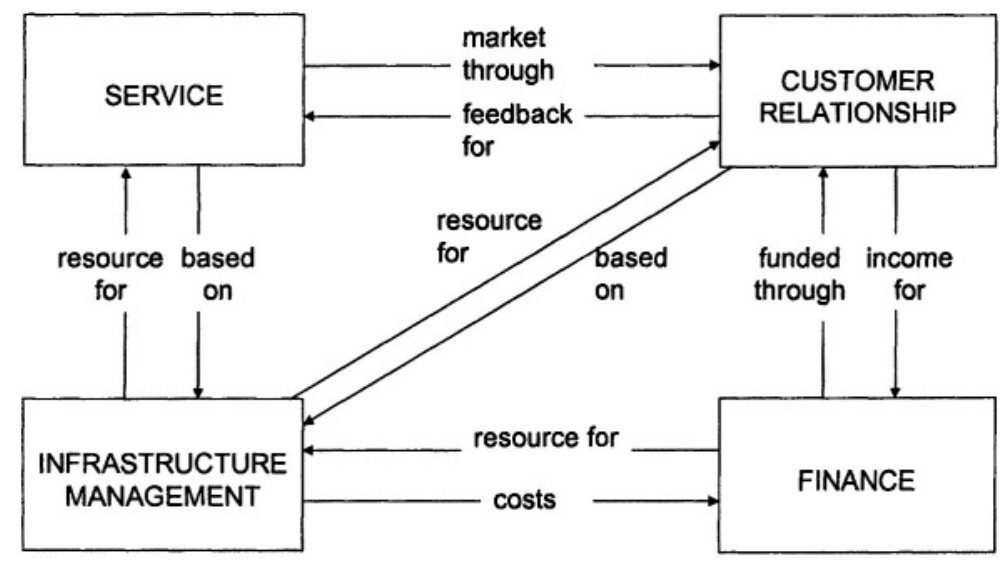

Figure 3. The four Components of Business Model Ontology (a simplified version of a figure by Osterwalder \& Pigneur, 2002)

In general, a business model represents primarily a single organization view. In reality, it is always linked to an outer context (figure 4. eFactors, 2002). In the long run, business model is applied to new markets (x-axis, spatio-temporal dimension). The feasibility of the business model in global markets is even more dependent on external variables, such as consumer 
preferences, employee competence (individual level), industry specific standards and business codes of conduct (industry) as well as cultural aspects and market regulations (society). The framework presented in Fig. 4. presents the complex interactions of a business model levels, and our limited prevailing (endogenous) view on it in the gray-shaded area. This framework expands nicely the previous static presentation of a business model on a space-time continuum and it can be used in analyzing business context in different market areas.

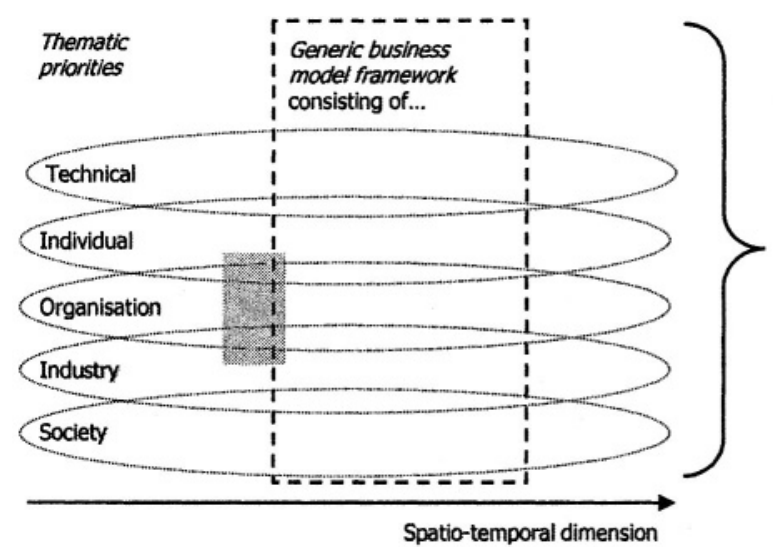

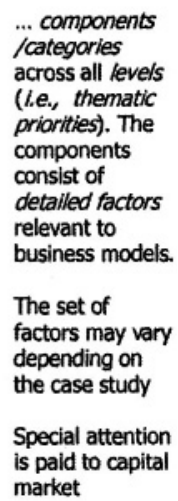

Figure 4. The eFactors framework (eFactors, 2002)

\subsection{Interoperable networked business models on a com- patible infrastructure?}

So far the research on (e-)business models has concentrated mainly on analyzing offering and customer relationships (according to Hedman \& Kalling, 2002) and limited effort is put on the profitability problems of infrastructure and operations (lower part of figure 3). However, Ciborra and Andreu (2001) point out that at infrastructure or resource level issues such as compatibility emerge almost immediately when setting up interorganizational alliances. Many ERP- or legacy systems may actually hinder the data transfer within the network. Information structure might, on the other hand, act also as a carrier of formative context. Thus, interorganizational systems are crucial, and can be considered as a planned and managed way to realize cooperation between organizations (e.g. Kumar \& vanDissel, 1996). 
An example of the qualitative change taking place in ICT-infrastructure towards e-business and partnerships is explored by Riihimaa and Ruohonen $(2002)^{31}$. First, the internal operative information systems are updated or integrated (ERP Phase). Secondly, the emphasis is put on supply chain processes within the corporation and/or with suppliers (SCM). The third phase is generally about better integration of customer relations management systems to previously mentioned ERP- and SCM-systems (CRM). As a fourth phase emerges Knowledge Management -Phase (KM), which requires even more profound knowledge about customers, suppliers and partners. In KM phase a firm is aiming at partnerships, in which knowledge is shared with the help of ICT networks. In this stage it is also possible to create innovative methods for producing, distributing and developing products. Service is included in the product, for instance maintenance and updates are enhancing the length of the customer relationship. Riihimaa and Ruohonen claim that it is difficult, or even impossible, for a firm to enter KM phase without going through the first three phases. It should be carefully analyzed how - and to what extent - data between various information systems should to be exchanged between organizations.

The above discussion on ICT-infrastructure based articulated business models illustrate our approach to the empirical setting. The basic challenge of ICT-enabled co-operation is that there are multiple participants with their own background, interests, business contexts, and individual strategies aiming at different product/market areas with specific schedule and by utilizing their proprietary technology stack and knowledge.

To conclude: if we know relatively little about the infrastructure in one company business model context, what do we know about the infrastructure for business models of networks of companies? Not much, we are afraid.

\section{THE CASE OF DEVELOPING GLOBAL SER- VICE CONCEPTS}

The motivation for this article arises from a practical case we are currently involved with: A consortium of three corporations (hereby called as $\mathrm{A}, \mathrm{B}$ and $\mathrm{C}$ ) and two research organizations. The consortium is focusing in primarily onto the clientele of the two consortium members (A and B). The

${ }^{31}$ Riihimaa and Ruohonen (2002) carried out 40 interviews in metal and electronics companies in Finland at the turn of the year 2001. Of the companies interviewed they categorized around $20 \%$ to being at ERP Phase, 50\% at SCM Phase, 20\% at CRM Phase, and 10\% at KM Phase. 
aim is to create joint ICT-supported business-to-business service offering of the three companies, thus enabling better response to customer needs. The researchers' role in the consortium is to aid in the process of communicating the needs and intentions of the parties to each other, and to help in forming an acceptable joint business model. This brings us to the discussion on strategies, business models and business processes. What sort of change in present domain, infrastructure, and revenue models of the consortium and also of each company we would need in order to succeed in co-operation? The consortium has to understand the differences in strategic intentions and 'paths' of the participating companies. Only against this backdrop it can formulate a network business model, which articulates the necessary changes, and facilitates communication and creation of shared understanding between the participants

\subsection{Strategic intentions and 'paths' of the companies}

Company A has become the leading supplier of capital goods on its own worldwide segment, and is generally considered also the technology leader in its field. It was company A that made the first move towards negotiations for establishing this consortium.

Figure 5. below is our interpretation of the changes of the company A on its way to present situation. The figure depicts the changes in its core competence, mode of co-operation and business network topology alongside with the evolution IS-architecture as they have emerged to support this evolution. 


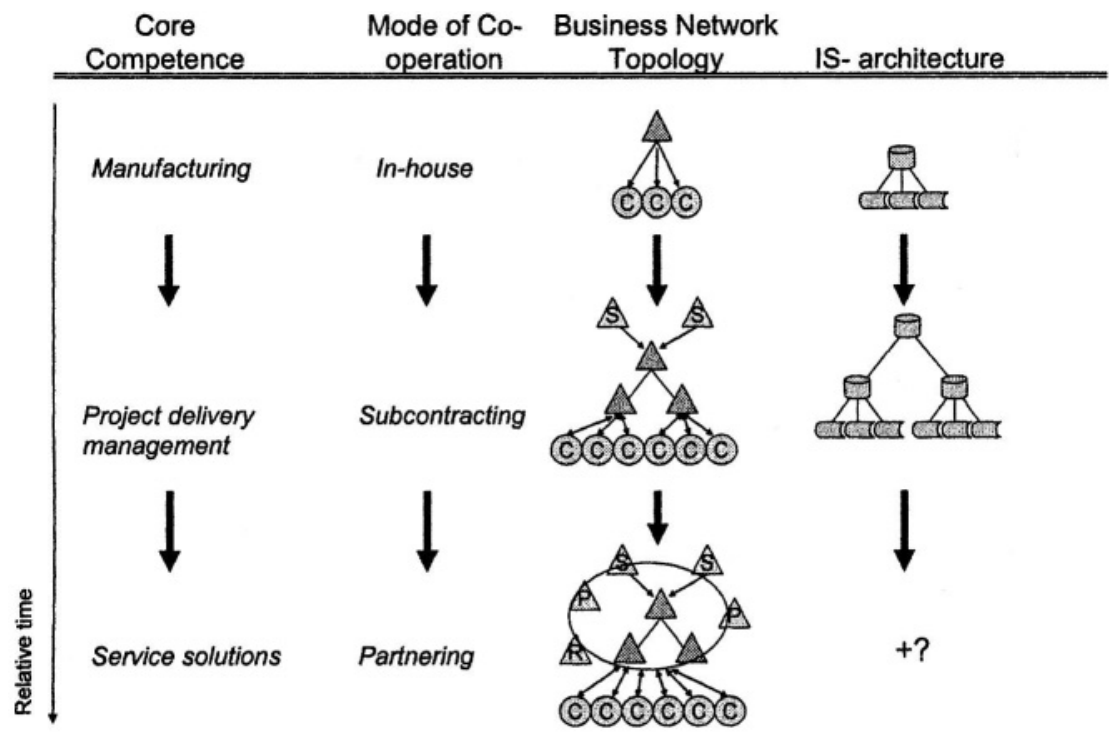

$\triangle$ Company, (C)Customer, S Supplier, \& Partner, \& Rival

Figure 5. Evolution of core competences, mode of co-operation, business network topology and IS-architecture of Company A.

The change in the core competence can be divided in the three major eras during the last two decades. In the beginning the Company A sold, manufactured, and delivered capital (b-to-b) goods as components from the single company under the supervision of customer representatives (i.e., project consultants) around the world. Automation and IT companies supplied separately the computerized information systems, which were needed to operate, diagnose and maintain production and processes on customers' sites.

The shift from production towards customer orientation started with delivery project management. As the degree of integration of the separate components grew at the customers end, it became feasible and necessary to coordinate the delivery and design stages of the individual components more closely with partners before and during the delivery. This means that the whole final equipment including automation and supporting ICT systems were supplied to customers in close co-operation with subcontractors, and Company A took the role of a coordinator in the delivery project (i.e., Moveto-the-Middle, Clemons et al., 1993). At present, the extreme cases are turnkey projects, when the company takes a main contractor role for the whole project with all components including automation and ICT systems configuration. The industrial and technical evolution (especially the growth of com- 
plexity) has thus changed the core competence of the industry from manufacturing to project delivery management.

The next step in the evolution of core competence of Company A has been stated in its business strategy: it is expected to move towards customer oriented service. The final outcome of this development might mean that operation and maintenance of the customers' equipment may be outsourced to an alliance of company A with its partners. There are requirements to increase profitability and meet the tighter quality standards set out by the customers' clients, and environmental restrictions by the authorities. The possibilities emerge along with the advances in ICT, remote diagnostics, control and coordination systems; on the other hand there is constant pressure to cut costs.

This development has had its implications on the information systems of company A. In the early stages the ICT-architecture was rather simple (in relative terms): one company solution with functional application software, the purpose of which was primarily to coordinate the intra-company product design, and planning of production. In the second stage the architecture was enhanced with distributed work support and document management, especially in terms of creating a knowledge base on the installed base and its configuration. The last phase would require a lot of synchronization with clients, partners, and even from competitors information systems to meet the needs of profitable, high quality service offerings.

Company B, a software house, has been moving towards more customer centric strategy. Until now it has acquired the needed additional industry specific knowledge primarily by company acquisitions. Its clientele includes among others Company A and C, and also many customers of Company A. So they share the same clientele, and are partially competitors in some product groups. Company B has developed its ICT infra to support partnering mode of co-operation.

Company $\mathrm{C}$, has been serving both $\mathrm{A}$ and $\mathrm{B}$, plus some of their clients. They primarily search for markets for their value-added infrastructure services, both by expanding the existing clientele and by providing new services to and with the companies of the consortium.

In summary, in order to carry on with their espoused strategies, our consortium companies can not operate alone any more. First, they need each other to complement each others' services cost-efficiently. They also are likely to need capabilities, knowledge and innovations from outside their own competence. This development is paced by the growing tendency of the 'end' clients to outsource parts of their business, and on the increasing use of networks for creating, storing and accessing knowledge to share and appropriate information that can not be produced internally. As stated by Powell (1990): "By improving the spread of information, they sustain the conditions 
for further innovation by bringing together different logics and novel combinations of information." As we are talking about worldwide business, it would mean also expansion of the network, so that there are local companies working together with global companies.

As the companies have separate self-interested strategies, they should agree on 'rules' for co-operation and formulate a joint service concept that would articulate the objectives of the consortium set by corporate strategies. It calls for considerable amount of trust and openness between the companies. In our consortium the companies decided to ask for facilitation from an independent university.

We have been involved with these topics for the past two years, and the synthesis presented in article is based on a pre-study in 2002, and the following data from MesoCompus-research project, 2003-2004: As of writing, we have had seven workshops, four open discussion steering group meetings, around 40 one partner meetings, and 12 transcribed interviews with specialists on the topic in company A and B. The data has been supplemented also with four company A headquarters personnel meetings. The process is documented in a non-disclosed diary (Newbury, 2001) by the university party.

\subsection{The Joint Development of Business Models}

Transformation from manufacturing to anticipated full-service orientation with the help of ICT seems to be emerging also in our case consortium as postulated e.g., by Powell (2000). The problem is that the consortium companies are still hesitating how deep into a co-operation they should engage, what are its consequences to their businesses, and how to deal with the information infrastructure. Our understanding of the situation is that this calls for articulated business model, which can serve as a basis for learning from the other partners, as a starting point for proofs-of-concepts, to reveal the trustworthiness of the partners, and also to communicate the potential in their own organizations. As the companies are operating on a global scale, world-wide knowledge management and inter-organizational learning must be facilitated by interoperable or shared IOS systems supporting - at least partially -joint practices.

The separate organizations participating in the network have naturally each own business strategies for the present and the future. Especially, if the network is to produce new innovative services or products, the companies should encage in a process of creating a joint business model to match its and each companies strategies (see figure below, the topmost horizontal shade). This means that the parties are to agree on the value proposition offered on the market; the target customers and CRM related aspects, other 
infrastructure and logistics issues, timing, and the revenue sharing model (to name some of the crucial characteristics of the business model offering and segmentation). This aims at describing the strategy-business model interface.

The above factors of business model are often uncertain and difficult to estimate in advance. For example, to be on the safe side, the partners are probably not willing to invest heavily in the beginning of the co-operation. Instead "As the trustworthiness of a potential partner is circumscribed in the beginning, firms do not commit large resources at one go, but engage in titfor-tat games where trust gradually builds up and a growing proportion of resources are invested in the relationship, forming a set of ties between the firms." (Andersen and Christensen, 2000).

As a consequence, the network emerges incrementally through mutual adjustment, commitment, communication, and resource transactions (van de Ven, 1976; Andersen \& Christensen, 2000). Moreover, especially in terms of information systems infrastructure the adjustment is an adaptive process depending on for instance organizations' histories, strategies, practices, hierarchies, cultures and infrastructure (Kumar \& van Dissel, 1996). Whenever cooperation and especially exploration approach (March, 1991) is wished for, the organizations must commit into an uncertain joint effort of creating business model incrementally, most likely with a light infrastructure (Ciborra \& Hanseth, 1998). We believe that this process requires extensive discussions and knowledge sharing between the participants. In these negotiations trustworthiness and alignment of motives of the parties can be validated.

We illustrate the creation of the joint business model as follows in Figure 6: The underlying blue triangle represents the business network's strategy, business model and processes (in a corresponding manner than in figure 2., Osterwalder \& Pigneur, 2002) to meet the customer demand. It is constructed by adjusting the companies' own business logic triangles $\mathrm{A}, \mathrm{B}$, and C with the network level business model (e.g., Gemünden et al., 1996). The individual business models are to be adjusted in four ways: First, horizontally at the strategy-business model -interface between the companies, and horizontally at the operative processes-business model -interface between the companies. Thirdly, they can be used 'vertically' within each company to align the strategies and processes to meet the challenges of co-operation. There is also an evident need for a fourth adjustment, namely to find new partners for the uncovered parts of the business model (the white spaces indicated by the arrows in the left and right at the business model -level). 


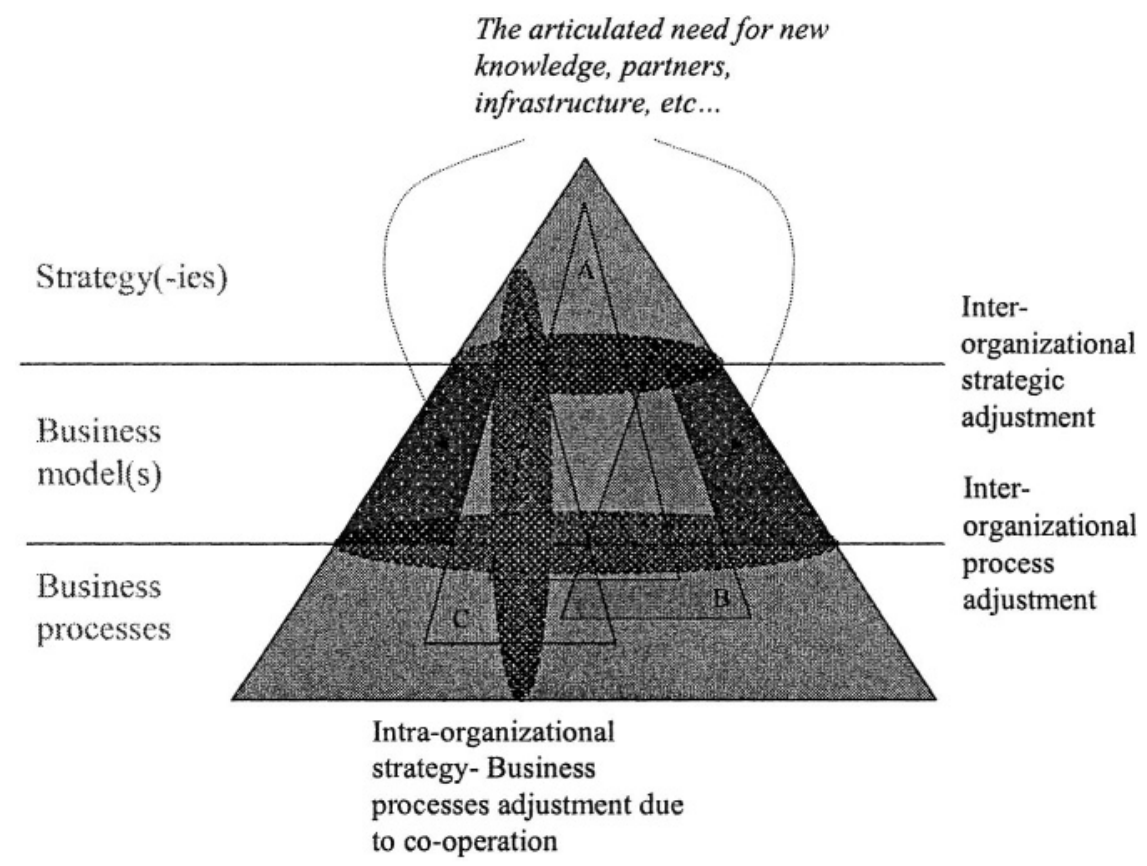

Figure 6. Joint development of network business model.

The first adjustment, between strategy and business model, is needed since individual strategies of participating companies are very unlikely to converge completely at network level. This is because the companies are specialized in their own fields (complementarity, van de Ven, 1976), and they are developing in the different pace towards co-operation. This means that if the companies are aiming at co-operation, they should be able to create a joint business model that is in line (Powell, 1990), or, sufficiently compatible with each company's own business strategy.

The second adjustment, between business model and operations, is needed to harmonize central operative processes between the companies of the network. As they even operate on different principles (or production types), there is an evident need to align at least some of the processes and ensure data compatibility. This will become even more important, when more companies join the network in the future. This is depicted in Figure 6. by letting individual business models to overlap on the processes-business model level. This overlap should cover the whole interface for interoperability reasons. This is important in our case, as the companies are looking for feasible ICT-enabled business model building upon their existing infrastructure and company specific ICT-architectures at a global scale. 
The two adjustment processes mean that the business model is a necessary means of articulation of joint activities between the companies' strategies and processes. It utilizes parts of the compatible infrastructure(s) of the network parties. The boundaries between strategy and business model, and between actual processes and business model can serve as starting points in creating the joint business model. The third adjustment should also take place within each company between strategy and processes, which are reflected in individual business models to ensure the strategic fitting, absorption of innovations, and change management.

Fourthly, the model is also helpful in recognizing the needs for new resources, capabilities, and partners, etc., to fill in the gaps in capabilities and resources of current or proposed partners in network.

\section{CONCLUSIONS}

In this paper we present a conceptual framework forjoint development of network business models. We have synthesized it for the purposes of an ongoing consortium aiming at developing a joint service offering relying on the extensive use of ICT. It relates the concepts of the absorptive capacity and adjustment of individual business models to the network's business model. This calls for matching the strategies and actual processes of each company with the joint business model. It points out vital adjustments processes that should be carried out in parallel to the sketching of components of a business model (in the sense of Osterwalder \& Pigneur, 2002).

More specifically, in the establishment of a joint business model for networked, ICT enabled operations, each company should: Firstly, reflect upon the joint business model and adjust their individual strategies; Secondly, the same kind of adjustment (although more concrete) should be done between the joint business model and actual business processes of each company; Thirdly, the business model can be used 'vertically' within each company to align the strategies and processes to meet the challenges of co-operation and absorbing innovations; and fourthly, the model is also helpful in recognizing the needs for new resources, capabilities, partners, etc., to fill in the gaps in the capabilities and resources of current partners in fulfilling the product/service offering.

Whether this analytical framework will be of use to our consortium remains to be seen. Yet, by combining the research on learning and knowledge sharing between firms with expanded business model ontology for networks, we think it may be useful in directing and framing future research. For instance, we can immediately raise questions such as: Is there any recommended ways to carry out the four adjustments cycles pointed out in the 
framework? How should we manage knowledge in business networks? How they can be supported with ICT? How can we explicitly incorporate dynamics to the business models?

\section{ACKNOWLEDGEMENTS}

This research was financially supported by the Academy of Finland, National Development Agency and the participating companies. We thank the three anonymous reviewers for their invaluable comments in improving this article.

\section{REFERENCES}

Alchian A. and Demsetz H. (1972), "Production, Information Costs and Economic Organization", American Economic Review, 4, pp. 777-795.

Andersen P.H. and Christensen P.R. (2000). "Inter-partner learning in global supply chains: lessons from NOVO Nordisk", European Journal of Purchasing \& Supply Management, 6 (2000), pp. 105-116.

Beugelsdijk S., Noorderhaven N. and Koen C. (2003) . "Organizational Culture, Alliance Capabilities and Social Capital", in the social capital workshop in Tilburg on March 27, 2003, 25 pages.

Bouwman H. (2003) "Designing metrics for business models describing Mobile services delivered by networked organisations", 16th Bled Electronic Commerce Conference eTransformation, Bled, Slovenia, June 9-11, 2003, 20 pages.

Ciborra C.U. and Andreu R. (2001). "Sharing knowledge across boundaries", Journal of Information Technology, Vol. 16, pp. 73-81.

Ciborra C.U. and Hanseth O. (1998). "Toward Contingency view of Infrastructure and Knowledge: An Explorative Study", Proceedings of the international conference on Information systems, Helsinki, Finland, 1998, pp. 263-272.

Clemons E., Reddi S. and Row M. (1993). "The impact of information technology on the organization of economic activity: The 'move to the middle' hypothesis", Journal of Management Information Systems, Fall 93, 10, 2, pp. 9-35.

Coase R. (1937), “The nature of the Firm”, Economica, 4, Nov. 1937, pp. 386-405.

Cohen W. and Levinthal D. (1990). "Absorptive Capacity: A New Perspective on Learning and Innovation”, Administrative Science Quarterly, 35, 1990, pp. 128-152.

Dyer J. and Singh H. (1998). "The relational view: Cooperative strategy and sources of interorganizational competitive advantage", Academy of Management Review, 23, No 4, pp. 660-679.

eFactors (2002). "WP3: E-business Model Roadmap", Deliverable 3.1. of Information Systems Technologies e-Factors Thematic Network Report, IST-2001-24868.

Faber E., Ballon P., Bouwman H., Haaker T., Rietkerk O. and Steen M. (2003). "Designing business models for mobile ICT services", 16th Bled Electronic Commerce Conference eTransformation, Bled, Slovenia, June 9-11, 2003, 14pages. 
Gemünden H.G., Ritter T., and Heyedebreck P., (1996). "Network configuration and innovation success: An empirical analysis in German high-tech industries", International Journal of Research in Marketing, Vol.13, pp. 449-462.

Gulati R. and Singh H. (1998), "The architecture of cooperation: Managing coordination costs and appropriation concerns in strategic alliances", Administrative Science Quarterly, Vol. 43, Issue 4, Dec 1998, pp. 781-814,.

Hammer M. (1990). "Reengineering work: Don't Automate, Obliterate”, Harvard Business Review, July-August 1990, pp. 104-112.

Hedman J. and Kalling T. (2002). "Analysing e-business Models", in Monteiro J., Swatman P., Tavares L. (eds.) "Towards The Knowledge Society: eCommerce, eBusiness, and eGovernment", The Second IFIP Conference on E-Commerce, E-Business, E-Government (I3E 2002), October 7-9, 2002, Lisbon, Portugal, Kluwer 2002, pp. 259-270.

Hagedoorn J. and Duysters G. (2002), "External Sources of Innovative Capabilities: The Preferences for Strategic Alliances or Mergers and Acquisitions", Journal of Management Studies, vol. 39 (2), pp. 167-88.

Hoogeweegen M., Teunissen W., Vervest P. and Wagenaar R. (1999). "Modular Network Design: Using information and Communication Technology to Allocate Production Tasks in a Virtual Organization”, Decision Sciences, Fall 1999, pp. 1073-1103.

Jensen M.C. and Meckling W.H. (1973), Theory of the Firm: Managerial behavior, agency costs and ownership structure, Journal of Financial Economics, Vol. 3 (Oct 1973), pp. 305-360.

Kumar K. and van Dissel H.G. (1996). "Sustainable collaboration. Managing conflict and cooperation in inter-organizational systems", MIS Quarterly, 1996, 20 (3), pp. 279-300

Malone T. Yates J. and Benjamin R. (1987), "Electronic Markets and Electronic Hierarchies", Communications of the ACM, 30, 6, pp. 484-497.

March J. (1991). "Exploration and exploitation in organizational learning", Organizational Science, Vol. 2, No. 1, February 1991, pp. 71-87.

Nalebuff B. and Brandenburger A. (1996). "Co-opetition", Profile Books, 1996, 288 pages.

Newbury D., (2001). "Diaries and Fieldnotes in the Research Process", Research Issues in Art Design and Media, Issue 1, (2001), The Research Training Initiative, University of Central England.

Nielsen B. (2002). "Synergies in Strategic Alliances: Motivation and Outcomes of Complementary and Synergistic Knowledge Networks", Journal of Knowledge Management Practices, Vol. 3, 2002, 26 pages.

Nooteboom B. (2000). "Learning by Interaction: Absorptive Capacity, Cognitive Distance and Governance", Journal of Management and Governance, 2000, 4, pp. 69-92.

Osterwalder (2004). "The Business Model Ontology: A Proposition in a Design Science Approach", Doctorate Thesis, 1'Ecole des Hautes Etudes Commerciales de l'Université de Lausanne, 172 pages.

Osterwalder A. and Pigneur Y. (2002). "An e-Business model ontology for modelling eBusiness". In the proceedings of the 15th Bled Conference on E-Commerce, Loebbecke et al. (eds.), 16-19 June 2002, Bled, Slovenia, 11 pages.

Picot A. Bortenlänger C. and Röhrl H. (1997). "Organization of Electronic Markets: Contributions from the New Institutional economics", The Information Society, Vol. 13, pp. 107-123.

Powell W.W. (1990). "Neither Markets nor Hierarchy: Network Forms of Organization", Research in Organizational Behavior, Vol 12, pp. 295-336.

Powell W.W. (2000). "The Capitalist Firm in the 21st Century: Emerging Patterns" in DiMaggio P., (ed.) (2003). "The Twenty-First-Century Firm: Changing Economic Organization in International Perspective", Princeton University Press, 275 pages 
Riihimaa J. and Ruohonen M. (2002). "Sähköisestä kaupasta osaamisliiketoimintaan Metalli- ja elektroniikkateollisuuden sähköisen liiketoiminnan strateginen suunta" (From eCommerce to Knowledge Based Business - The Strategic Directions of eBusiness in Metal and Electronics Industries), Metalliteollisuuden Keskusliiton julkaisuja, 2002, 86 pages, in Finnish.

Sivadas E. and Dwyer R. (2000). "An Examination of Organizational Factors Influencing New Product Success in Internal and Alliance-Based Processes", Journal of Marketing, Vol. 64, pp. 31-49.

Timmers P. (1998). "Business Models for Electronic Markets", In Gadient, Yves; Schmid, Beat F.; Selz, Dorian: (eds.) Electronic Commerce in Europe. Electronic Markets, Vol. 8, No. 2, 07.98.

Tsupari P., Nissinen T. and Urrila P. (2001). "Kohti strategisia yritysverkkoja: Osaraportti I Teollisuuden verkottumisen yleiskatsaus" (Towards Strategic Enterprise Networks: Report I An Overview of the Networking in the Industry), Teollisuuden ja Työnantajain Keskusliiton julkaisuja, 2001, 42 pages, in Finnish.

van de Ven A.H. (1976). "On the Nature, Formation, and Maintenance of Relations Among Organizations", Academy of Management Review, 1976, pp. 24-34.

Williamson O.E. (1985). "The Economic Institutions of Capitalism; Firms, Markets, Relational Contracting", The Free Press, New York, 1985, 450 pages. 